\title{
Peningkatan Kompetensi Mengembangkan RPP melalui Lesson Study bagi Guru SD Laboratorium
}

\author{
Achmad Supriyanto $^{1}$, Wasih DS ${ }^{2}$, Roni Herdianto ${ }^{3,1}$ \\ ${ }^{1}$ Universitas Negeri Malang \\ ${ }^{2}$ SD Laboratorium UM Kota Blitar \\ ${ }^{3}$ ASCEE Indonesia
}

\begin{abstract}
INFO ARTIKEL
\section{Riwayat Artikel:}

Diterima: 12-12-2019

Disetujui: 19-02-2020

\section{Kata kunci:}

lesson study competence; developing; lesson plans; lesson study; kompetensi; mengembangkan;
\end{abstract} $R P P$

\section{Alamat Korespondensi:}

Achmad Supriyanto

Universitas Negeri Malang

Jalan Semarang 5 Malang

E-mail: a.supriyanto.fip@um.ac.id

Rencana pelaksanaan pembelajaran merupakan persiapan mengajar tertulis yang dibuat setiap guru untuk membelajarkan siswa secara terprogram sesuai kurikulum yang berlaku. RPP dikembangkan berdasarkan silabus untuk memberi arahan kepada guru dalam pembelajaran yang dikelolanya (Kim, 2016; Owiny, 2019). Berdasarkan hasil pengamatan terhadap RPP yang dikembangkan oleh guru di satuan pendidikan, dan RPP yang dikembangkan di kelompok kerja guru masih ditemukan adanya ketimpangan-ketimpangan. Jika dianalisis dengan cermat ketimpangan tersebut terjadi karena ketidaktepatan guru dalam menganalisis kompetensi dasar (KD) sebelum mengembangkan RPP.

Kompetensi menganalisis KD merupakan syarat penting untuk dipenuhi agar pembelajaran dapat mencapai kompetensi minimal yang disyaratkan oleh KD. KD itu sendiri merupakan kemampuan dan materi pembelajaran minimal yang harus dicapai oleh peserta didik secara nasional untuk suatu mata pelajaran pada masing-masing satuan pendidikan yang mengacu pada kompetensi inti (Permendikbud No .22/ 2016). Artinya bahwa materi pembelajaran yang tersurat dan yang tersirat dalam KD tersebut merupakan batasan minimal dari kompetensi yang harus dicapai oleh semua peserta didik di seluruh wilayah tanah air tanpa perkecualian. Berdasarkan pengertian KD tersebut maka guru haruslah memiliki kompetensi memaknai/menganalisis dengan baik statemen-statemen dalam setiap KD agar pembelajaran sesuai dengan pesan yang tersurat maupun yang tersirat dalam KD. 
Kemampuan mengembangkan rencana pelaksanaan pembelajaran merupakan kompetensi guru yang esensial (Rahmatullah, 2016; Voss, 2017). Mengajar tanpa persiapan sama halnya dengan berjalan tanpa tujuan. Sementara pembelajaran itu harus jelas tujuan apa yang akan dicapai (Bachri, 2010; Pane \& Dasopang, 2017). Disebutkan bahwa diantara komponen penting dalam RPP adalah indikator pencapaian kompetensi dan tujuan pembelajaran (Munasik, 2015). Dua komponen ini dijabarkan dari KD. Komponen indikator dan tujuan pembelajaran inilah yang dijadikan kompas untuk merancang pelaksanaan pembelajaran secara utuh. Kedua komponen RPP tersebut dijadikan acuan untuk mengembangkan materi dan skenario pembelajaran, alat penilaian, memilih media dan sumber pembelajaran yang relevan (Lubis et al., 2017; Astuti, 2018). Jadi, kunci berkualitas tidaknya RPP terletak pada kualitas dua komponen tersebut. Oleh karena itu, setiap KD perlu dimaknai/dianalisis, kemudian berdasarkan pemaknaan tersebut diuraikan/dijabarkan menjadi indikator-indikator pencapaian kompetensi. Agar terukur dan teramati maka untuk merumuskan indikator digunakan kata kerja operasional (KKO). KKO adalah kata-kata kerja yang jika rangkai dalam sebuah indikator dapat diamati dan diukur (Bagus \& Sujatmiko, 2019). Contoh KKO: menunjukkan, menyebutkan, menjelaskan, menyatakan pendapat, membilang secara berurutan dan sebagainya. Kenyataan di sekolah masih banyak ditemukan rumusam indikator belum sesuai dengan KD nya. Hal ini jelas berdampak pada rumusan tujuan pembelajar-an yang menjadi belum padu dengan pesan KD yang harus dicapai. Kelemahan ini disebabkan oleh keterbatasan guru dalam memaknai KD secara benar. Hasil pengamatan terhadap RPP yang dibuat guru dipaparkan sebagai berikut.

Sebagai contoh analisis KD yang belum mencerminkan pencapaian KD, diambil dari RPP dengan muatan pelajaran PPKn KELAS IV semester I dengan KD 3.2: Memahami hak dan kewajiban sebagai warga negara dalam kehidupan sehari-hari di rumah, sekolah, dan masyarakat. Untuk KD 4.2: Melaksanakan kewajiban sebagai warga di lingkungan rumah, sekolah, dan masyarakat. Rumusan indikator yang dibuat guru belum mencerminkan pencapaian pesan KD 3.2. Indikator untuk KD 4.2 tidak dibuat, seharusnya KD 4.2 juga dibuatkan indikatornya, karena penyusunan KD-KD dari kompetensi Pengetahuan sudah langsung disandingkan dengan KD Keterampilan, agar sinkron antara pengetahuan (knowledge) dengan keterampilan (psikomotor) yang dikembangkan. KD 3.2 dan 4.2 yang akan dikembangkan RPPnya tersebut perlu dianalisis dulu pesan apa yang tersurat dalam $\mathrm{KD}$, dari segi pengetahuan/kognitifnya, sikap dan keterampilannya. Berdasarkan pernyataan dalam KD 3.2 dan 4.2 tersebut dicontohkan pemaknaan/analisis KDnya terhadap kompetensi minimal dari domain pengetahuan dan keterampilan yang harus dicapai peserta didik. Contoh analisis KD ditabulasikan pada tabel 1 adalah hasil analisis KD, yang memuat indikator yang mencerminkan pesan KD, dan contoh indikator hasil analisis KD yang dibuat guru.

Berdasarkan contoh di atas diketahui bahwa indikator pencapaian kompetensi yang dibuat guru belum mencerminkan capaian yang tersurat dalam KD. Jika indikator dan tujuan pembelajaran tidak sejalan dengan pesan KD, maka KD sebagai batas minimal kompetensi yang harus dicapai peserta didik tidak mungkin dapat tercapai. Untuk itulah maka diperlukan kepiawaian guru untuk menganalisis pesan yang tersurat dalam KD secara tepat. Diharapkan melalui kegiatan Lesson Study antara guru dengan kepala sekolah dalam proses penyusunan RPP, keterbatasan kompetensi menganalisis KD untuk dijabarkan menjadi indikator dan dikembangkan menjadi tujuan pembelajaran yang padu/matcth dapat diatasi. Kegiatan ini sebagai perwujudan dari upaya peningkatan kemampuan guru dalam mengemban Undang-undang Nomor 14 Tahun 2005 tentang Guru dan Dosen yang menuntut bahwa guru profesional adalah guru yang memiliki kualifikasi akademik, kompetensi, dan sertifikat pendidik yang disyaratkan. Kompetensi yang dimaksud adalah kompetensi peda-gogik, kompetensi kepribadian, kompetensi sosial, dan kompetensi profesional.

Untuk mengatasi kesenjangan tersebut ditawarkan solusi pemecahannya melalui penerapan Model Pembinaan Profesi Pendidik yang disebut Lesson Study (Lewis et al., 2006; Fernandez, 2002; Lewis et al., 2009). Hendayana, dkk. (2006) mengartikan "Lesson Study" adalah model pembinaan profesi pendidik melalui pengkajian pembelajaran secara kolaboratif dan berkelanjutan berlandaskan prinsip-prinsip kolegalitas dan mutual learning untuk membangun komunitas belajar". Dalam implementasinya Lesson Study terdiri dari tiga tahap, yaitu (1) plan/perencanaan, (2) do/melaksanakan, dan (3) see/merefleksi. Seluruh guru harus terlibat langsung dalam tahapan Lesson Study ini. Keikutsertaan seluruh guru ini penting karena dengan terlibat dalam seluruh tahapan, maka dalam diri mereka akan terbentuk kolaborasi kerja yang optimal.

Dipilihnya alternatif ini karena diyakini bahwa melalui Lesson Study para guru akan memperoleh pengalaman dan wawasan keprofesionalan melalui kolaborasi dengan kolega akan dapat memperbaiki kompetensi dalam mendesain RPP. Kegiatan sekelompok guru secara kolaboratif dan berkesinambungan seperti ini merupakan bentuk aktualisasi pembinaan untuk meningkatkan kompetensi merencanakan pembelajaran. Hal ini sejalan dengan hasil penelitian dari Slamet, HW, dkk. (2010) bahwa dua dari tujuh hasil penelitiannya dengan Lesson Study memberi informasi bahwa "kompetensi pedagogik, yaitu kemampuan dalam pengembangan kurikulum/silabus dan perencanaan pembelajaran dapat meningkat”. Jadi, berdasarkan temuan penelitian tersebut dapat diperoleh informasi bahwa pembinaan guru melalui Lesson Study dapat meningkatkan kompetensi mengembangkan perencanaan pembelajaran.

Temuan penelitian lain yang senada dengan temuan di atas adalah penelitian dari Dionisius (2017) yang mengatakan bahwa Lesson Study membantu guru dalam hal merancang program pembelajaran (RPP) yang berkualitas. Alasan lain yang menguatkan pemilihan alternatif ini adalah pernyataan Lewis (2002) dalam Susilo et al (2011) terkait dengan pembinaan guru untuk meningkatkan kompetensi guru merancang RPP mengatakan bahwa Lesson Study memberikan sumbangan delapan pengalaman pengembangan keprofesionalan guru, salah satu diantaranya adalah poin 5 yang menyatakan memberi pengalaman merancang pembelajaran secara kolaboratif'. Temuan penelitian lain menyebutkan Peningkatan keprofesionalan guru terjadi pada 
tim Lesson Study atas nama Dyah Kusuma, yang ditunjukkan oleh peningkatan nilai dengan predikat "kurang" pada siklus I, meningkat menjadi nilai "sangat baik" pada siklus V (Arsy, et al., 2014).

Tabel 1. Contoh Pemaknaan KD, dan Kesenjangan Rumusan Indikator yang Mencerminkan Pesan KD, disandingkan dengan Indikator yang Dibuat Guru

\begin{tabular}{l}
\hline \multicolumn{1}{c}{ Rumusan KD } \\
\hline KD 3.2: Memahami hak \\
dan kewajiban sebagai \\
warga negara dalam \\
kehidupan sehari-hari di \\
rumah, sekolah, dan \\
masyarakat. \\
(contoh yang dianalisis \\
hak dan kewajiban anak \\
sebagai warga negara di \\
lingkungan rumah)
\end{tabular}

KD 4.2 Melaksanakan kewajiban sebagai warga di lingkungan rumah, sekolah, dan masyarakat.
Kegiatan melaksanakan kewajiban di rumah, misal menyapu lantai rumah dan halaman, membantu mencuci peralatan makan sesudah makan, membersihkan dan menata tempat tidur, menyiapkan sendiri peralatan sekolah.
Fakta hak dan kewajiban dalam kehidupan sehari-hari di rumah: hak anak di rumah mendapat perlindungan, pemenuhan kebutuhan pokok, pendidikan, kesehatan, keamanan. Kewajiban anak di rumah: mematuhi dan melaksanakan peraturan di rumah, membantu meringankan pekerjaan orang tua di rumah.
1. Menyebutkan dua contoh hak anak di rumah

2. Menyebutkan tiga kebutuhan pokok

3. Menyebutkan dua contoh kewajiban anak di rumah

4. Memberi dua contoh pekerjaan untuk membantu meringankan pekerjaan orang tua di rumah

5. Mengemukakan pendapat terhadap kondisi jika peraturan di rumah tidak dipatuhi dan tidak dilaksanakan

1. Membuat jadwal kegiatan di rumah dibantu orang tua (membersihkan dan menata tempat tidur setelah bangun tidur, menyirami tanaman, membantu mencuci sendiri peralatan makan)

2. Melaporkan kegiatan yang telah dilakukan di rumah, yang ditandatangani orang tua.
Contoh Indikator yang Dibuat Guru memberikan tiga contoh kewajiban manusia terhadap hewan dan tumbuhan.

tidak dibuat

tidak dibuat

Catatan: analisis dilanjutkan untuk sub KD di

lingkungan sekolah dan masysrakat.

Melalui Lesson Study ini semua guru diajak untuk berkolaborasi dalam kegiatan menyusun RPP sesuai kelas dan mata pelajaran yang diampunya. Inilah kerangka berpikir yang dijadikan landasan untuk merencanakan penelitian tindakan sekolah di SD Laboratorium UM Kota Blitar. Dari kerangka berpikir ini tujuan dilakukannya PTS adalah untuk mengungkap dan mendeskripsikan kompetensi guru dalam (1) menganalisis KD, (2) menjabarkan KD ke dalam indikator pencapaian kompetensi, (3) mengembangkan tujuan pembelajaran berdasarkan rumusan indikatornya, (4) merancang penilaian berdasarkan rumusan tujuan pembelajarannya, (5) mengembangkan materi pembelajaran untuk mencapai tujuan pembelajarannya, (6) memilih media, (7) memilih sumber belajar, dan (8) merancang pendahuluan pembelajaran, (9) merancang kegiatan inti pembelajaran, dan (10) merancang kegiatan menutup/akhir pembelajaran. Skor rerata dari akumulasi sepuluh (10) kompetensi merancang komponen RPP tersebut menunjukkan hasil akhir berupa kompetensi mengembangkan RPP.

\section{METODE}

Rancangan penelitian yang digunakan dalam penelitian ini adalah rancangan penelitian tindakan kelas dari Kemmis dan Mc. Taggart (1988). Penelitian ini merupakan penelitian bersiklus. Setiap satu siklus penelitian terdiri dari empat (4) tahapan penelitian yang berlangsung berulang sampai target penelitian tercapai. Empat tahapan dalam satu siklus penelitian meliputi perencanaan (planning), tindakan (action), pengamatan (observation), dan refleksi (reflection). Dengan dilakukannya pengulangan ini diharapkan terjadi peningkatan dari sasaran penelitian yang akan dicapai.

Subjek penelitian adalah semua guru SD Laboratorium UM Blitar sebanyak sebelas orang. Delapan orang merupakan guru kelas, dari kelas 1-6; tiga orang guru muatan pelajaran Pendidikan Agama dan Budipekerti, PJOK, dan SBdP. Instrumen penelitian yang digunakan adalah (1) Tabel Kerja 1-5 dan (2) buku catatan lapangan untuk mencatat data-data pengamatan selama penelitian. Data PTS yang terkumpul dianalisis dengan teknik analisis data yang diadaptasi dari Miles dan Huberman, 1992 yang terdiri atas tahapan mereduksi data, menyajikan data, menarik kesimpulan, dan verifikasi. Dari keseluruhan data yang terkumpul dipilah sesuai dengan tujuan penelitian. 
Proses menyeleksi, menentukan fokus, menyederhanakan, meringkas, dan mengubah bentuk data "lengkap" yang terdapat dalam catatan lapangan disebut sebagai proses reduksi data (Susilo et al., 2008). Data yang sudah terkumpul dan dipilah, direduksi untuk diringkas menjadi dua kelompok data utama, yaitu data rekapitulasi capaian skor setiap kompetensi merancang/mengembangkan komponen RPP oleh masing-masing subjek dan skor reratanya, kelompok data kedua adalah kelompok data rekapitulasi skor rerata setiap kompetensi merancang/mengembangkan komponen RPP nilai dan predikat nilai dari masing-masing komponen RPP dan RPPnya. Jadi, reduksi data merupakan kegiatan menstrukurisasi/menyusun kembali data agar menjadi lebih komunikatif melalui tampilan yang sederhana, dalam arti data mentah yang belum terstruktur dipilah dan diubah menjadi data matang yang komunikatif dan sistematis disesuaikan dengan tujuan penelitian. Data matang inilah yang nanti disajikan dan selanjutnya dipaparkan. PTS ini dilaksanakan dalam dua siklus yang dilaksanakan dalam bulan Desember 2017April 2018. Dalam setiap siklusnya dilakukan kegiatan pengembangan RPP dengan menerapkan Lesson Study. Berikut disajikan paparan tahapan penelitian yang dilakukan.

\section{Perencanaan Siklus I}

Kegiatan yang dilakukan pada tahap perencanaan, meliputi (1) menyiapkan jadwal dan materi untuk workshop pengembangan RPP melalui Lesson Study, (2) menyusun instrumen PTS berupa Tabel Kerja 1-5. Tabel-tabel kerja tersebut digunakan untuk mengumpulkan data kompetensi guru dari aspek-aspek (a) kompetensi guru menganalisis KD; (b) kompetensi guru menjabarkan KD ke dalam indikator pencapaian kompetensi dan mengembangkan indikator menjadi tujuan pembelajaran; (c) kompetensi guru mengembangkan alat penilaian pengetahuan berdasarkan indikator dan tujuan pembelajarannya; (d) kompetensi guru mengembangkan materi pembelajaran, memilih media dan sumber pembelajaran berdasarkan tujuan pembelajaran; (e) merancang skenario pembelajaran, (3) menyiapkan instrumen untuk telaah RPP hasil PTS, dan (4) menyiapkan buku catatan lapangan terkait pelaksanaan lesson study.

\section{Pelaksanaan Tindakan Siklus I}

Kegiatan-kegiatan yang dilakukan pada tahap tindakan siklus I, meliputi (1) guru subjek PTS melakukan tahap plan melalui kegiatan diskusi kelompok kecil mata pelajaran serumpun dan kelompok kecil guru kelas untuk kelas rendah (kelas 1 3) untuk memilih KD yang akan dikembangkan RPP nya, dilanjutkan tahap do mengerjakan tabel kerja $1-5$, dan terakhir menyusun RPP yang utuh berdasarkan hasil kerja dari tabel kerja $1-5$ dengan format RPP K-13, diakhiri dengan tahap refleksi/see melalui kegiatan presentasi RPP yang disusun guru subjek PTS dalam kegiatan pleno. RPP yang dipresentasikan dalam pleno dikomentari, dikonfirmasi, dan direvisi. RPP yang telah di revisi merupakan RPP hasil PTS yang selanjutnya oleh peneliti akan ditelaah dengan Lembar Telaah RPP K-13 pada tahap observasi. Setiap tahapan Lesson Study dalam kegiatan penelitian ini berlansung lancar. Semua guru antusias dalam melaksanakan dari tahap plan, do, dan see.

\section{Observasi Siklus 1}

Kegiatan yang dilakukan dalam tahap observasi adalah (1) menilai hasil kerja tabel kerja $1-5$ dengan mengacu pada pedoman pensekoran yang telah dibuat sesuai kompetensi yang dikembangkan, dan (2) menilai RPP hasil kerja 11 orang guru subjek PTS dengan menggunakan Lembar Telaah RPP K-13 dari hasil Kegiatan Workshop Pendampingan Implementasi K- 13 Bagi Kepala Sekolah Se-Kota Blitar, yang diselenggarakan oleh Dinas Pendidikan Kota Blitar pada bulan Juni 2017. Semua data yang terkumpul dibuatkan tabel data berdasarkan kelompok data. Berdasarkan kelompok data yang diperlukan dalam penelitian ini terdapat sepuluh (10) kelompok data seperti yang dipaparkan pada bagian pendahuluan. Kesepuluh kelompok data ini direkap dalam satu tabel data yaitu tabel 2 Rekapitulasi Skor Kompetensi Guru Mengembangkan Sepuluh Komponen RPP pada siklus I dan II.

\section{Refleksi Siklus I}

Kegiatan yang dilakukan pada tahap refleksi adalah meninjau ulang terhadap semua data penelitian yang terkumpul dikelompokkan dan dianalisis. Analisis data yang digunakan adalah analisis data secara kualitatif yaitu dengan menghitung skor reratanya. Jika skor rerata sudah mencapai target nilai dengan predikat baik maka penelitian dihentikan.

Selanjutnya, data kesepuluh kompetensi guru mengembangkan komponen RPP yang sudah terkumpul, direduksi menjadi dua (2) kelompok data yaitu pertama data rekapitulasi dari kompetensi guru mengembangkan 10 komponen RPP (pada Tabel 2) dan yang kedua data rekapitulasi skor rerata kompetensi mengembangkan 10 komponen RPP, skor rerata RPP dan poin peningkatan dari siklus I ke II (Tabel 3). Dari kegiatan ini diperoleh kesimpulan sementara dan temuan-temuan penting penelitian.

Berdasarkan hasil analisis data dan temuan penelitian tersebut digunakan sebagai pijakan untuk menindaklanjuti sesuai yang direkomendasikan dari hasil analisis data. Jika terbukti bahwa baik secara individu maupun secara rata-rata kompetensi guru subjek PTS pada siklus I dalam mengembangkan RPP masih belum memenuhi target penelitian, dalam arti secara rata-rata masih belum mencapai nilai dengan predikat baik dengan rentang skor 86 — 90, maka PTS berlanjut ke siklus II, dengan langkah-langkah yang sama seperti di siklus I. 


\section{Penelitian Tindakan Sekolah Siklus II}

Tahapan kegiatan PTS pada siklus II dimulai dari perencanaan sampai refleksi sama seperti yang terjadi pada siklus I. Jenis instrumen yang digunakan dan teknik pengambilan data juga sama. Yang membedakan adalah KD yang dipilih oleh subjek penelitian. KD yang dipilih disesuaikan dengan pembelajaran yang akan dikembangkan di kelas pada waktu itu.

Tahap tindakan PTS II diaktualisasikan melalui kegiatan Lesson Study oleh subjek PTS mulai dari tahap perencanaan (plan) sampai dengan tahap see/merefleksi yang dilakukan di siklus 1 berlangsung kurang optimal, karena berbenturan dengan kegiatan sekolah yang padat serta beban mengajar guru yang banyak. Kegiatan sekolah di semester genap cukup padat misalnya kegiatan tryout bagi siswa kelas 6, kegiatan ujian sekolah, ujian sekolah berstandar nasional (USBN), ujian praktik muatan-muatan pelajaran bagi siswa kelas VI yang berlangsung di bulan Februari-Mei 2018.

Kurang optimalnya pelaksanaan lesson study terletak pada pelaksanaan tahap see. Tahap see tidak dapat dilakukan melalui presentasi dalam pleno, tetapi langsung melalui penilaian dokumen hasil kerja guru mulai dari mengerjakan tugas Tabel Keja 1 sampai dengan Tabel Kerja 4 oleh peneliti, serta merangkai hasil kerja Tabel Kerja $1-5$ sehingga menjadi RPP siklus II yang utuh. Jika masih banyak kekurangan, maka hasil kerja dikembalikan untuk diperbaiki sesuai saran masukan dari peneliti.

Tahap observasi PTS II dilaksanakan dalam bentuk kegiatan penilaian dokumen hasil kerja subjek PTS hasil revisi pada tahap see dengan menggunakan instrumen dan teknik pengumpulan data yang sama seperti pada siklus 1 . Data ini disajikan pada Tabel 2. Data dari tabel 2 ini dianalisis lebih lanjut disajikan dalam tabel 3 yang memuat skor rerata, nilai serta predikatnya untuk sepuluh komponen RPP, serta poin peningkatan skor masing-masing komponen RPP pada siklus I ke siklus II.

Besaran peningkatan kompetensi dihitung dari perolehan poin pertambahan skor. Dari poin pertambahan skor tersebut dapat diketahui terjadinya peningkatan kompetensi subjek dari siklus I ke siklus II secara kuantitatif, maupun secara kualitatif. Sangat dimungkinkan bahwa peningkatan hanya secara kuantitatif, namun secara kualitatif stagnan (tidak terjadi peningkatan predikat nilai). Jika pada hasil penelitian pada siklus II ini sudah memenuhi target PTS, yaitu tercapainya nilai rerata kompetensi mengembangkan RPP oleh subjek dengan predikat baik, maka PTS dihentikan. Namun, jika target nilai rerata baik belum tercapai, maka PTS perlu terus dilanjutkan ke siklus III.

\section{HASIL dan PEMBAHASAN}

\section{Penelitian Tindakan Sekolah Siklus I}

Pelaksanaan Lesson Study pada PTS siklus I berjalan sesuai dengan prosedur/tahap-tahap Lesson Study. Kegiatan yang dilakukan oleh subjek pada tahap plan adalah diskusi dalam kelompok kecil berdasarkan kelas yang diampu dan berdasarkan muatan pelajaran yang diampu. Dari diskusi ini dihasilkan (a) KD terpilih yang akan dikembangkan menjadi RPP, (b) hasil analisis KD yang tertuang dalam Tabel Kerja 1; (c) hasil rumusan indikator dan tujuan pembelajaran pada Tabel Kerja 2, (d) hasil pengembangan alat penilaian pengetahuan pada Tabel Kerja 3, dan (e) hasil pengembangan materi pembeljaran, pemilihan media, dan pemilihan buku sumber pada Tabel Kerja 4, (f) hasil pengembangan skenario pembelajaran pada Tabel kerja 5. Data pada tabel kerja $1-5$ direkap dalam satu tabel menjadi tabel 2 .

Pengerjaan semua tugas pada tahap plan didampingi oleh peneliti. Selanjutnya, setiap tabel kerja hasil penelitian diverifikasi oleh peneliti, jika masih ditemukan kekurangan maka kepada subjek diberi kesempatan untuk memperbaiki sesuai saran. Kegiatan subjek pada tahap plan di siklus I berlangsung sangat lancar, semua subjek PTS tampak terlibat aktif dalam diskusi. Pelaksanaan tahap do adalah merangkai secara individual semua hasil kerja pada tahap plan menjadi sebuah RPP yang utuh. RPP yang telah jadi ditindaklanjuti ke tahap see/refleksi. Setiap subjek melaksanakan tahap do siklus I dengan penuh antusias dan lancar. Namun, pada tahap do terdapat tiga, (3) subjek yang menyelesaikan tugas tidak tepat waktu.

Tahap see dikemas dalam bentuk diskusi pleno untuk mempresentasikan RPP yang sudah jadi. Dalam diskusi pleno ini RPP yang dipresentasikan diberi masukan oleh kelompok lain, dan peneliti. Masukan tersebut digunakan sebagai bahan untuk memperbaiki/merevisi. Masukan yang diajukan berkenaan dengan sinkronisasi antara rumusan indikator dan tujuan pembelajaran dengan $\mathrm{KD}$, anatara butir soal dengan indikator dan atau tujuan pembelajaran, kelengkapan pengembangan materi pembelajaran ditinjau dari tujuan pembelajarannya. RPP hasil revisi merupakan RPP hasil akhir PTS pada siklus 1, untuk diobservasi dan dinilai oleh peneliti. Pelaksanaan tahap see PTS siklus I berlangsung lancar, semua subjek terlibat aktif dalam diskusi pleno. Hasil tersebut dapat dilihat pada tabel 2. Data pada tabel 2 memberi informasi berkenaan dengan data kompetensi pengembangan/perancangan setiap komponen RPP oleh masing-masing subjek pada siklus I yang disandingkan dengan data pada siklus II sehingga secara langsung dapat diketahui poin peningkatannya. Dari data tersebut dapat terbaca adanya peningkatan skor/peningkatan kuantitatif dari siklus I ke siklus II.

Pada siklus I tampak kompetensi subjek mengembangkan RPP masih variatif. Hal tersebut ditunjukkan oleh bervariasinya capaian nilai masing-masing subjek. Dari 11 orang subjek terdapat satu orang $(9,09 \%)$ yang nilainya berpredikat K (perlu bimbingan), 8 orang subjek (72,73\%) nilainya berpredikat Cukup (C), dan hanya dua orang subjek $(18,18 \%)$ berpredikat Baik (B). Hasil seperti ini dapat dipahami karena pada siklus I ini pada umumnya subjek penelitian masih belum baik pemahamannya terhadap pengembangan masing-masing komponen RPP. Kebiasaan yang dilakukan dalam membuat RPP tidak pernah melalui tahapan-tahapan yang hirarkis berdasarkan keterkaitan antara komponen RPP yang satu dengan yang lain. Keterkaitan tersebut perlu diperhatikan agar pesan KD dapat terpenuhi. Pernyataan ini sudah sesuai dengan prisip penyusunan RPP K-13 pada poin "f" yang menyatakan penyusunan RPP perlu memperhatikan penekanan pada keterkaitan dan keterpaduan 
antara KD materi pembelajaran-kegiatan pembelajaran-indikator pencapaian kompetensi-penilaian-sumber belajar dalam satu keutuhan pengalaman belajar.

Pada siklus I ini para subjek penelitian pada umumnya masih kurang kompeten melakukan analisis KD. Didalam analisis KD terdapat kegiatan mengidentifikasi fakta dan konsep yang tersurat dalam KD. Fakta dan konsep hasil analisis KD merupakan acuan untuk mengembangkan materi pembelajaran. Pernyataan ini didukung oleh deskripsi komponen RPP poin " $h$ " yang dimuat dalam Standar Proses Tahun 2016 yang berbunyi fakta, konsep, prinsip, dan prosedur yang relevan (masudnya relevan dengan KD) dimuat dalam materi pembelajaran, sesuai dengan rumusan indikatornya (Permendikbud Nomor 22 Tahun 2016). Tabel 3 memuat hasil analisis data dari tabel kerja $1-5$ pada siklus I dan II, sedangkan tabel 4 menunjukkan hasil rekapitulasi persentase capaian predikat nilai pada siklus I dan II.

Tabel 3. Rekapitulasi Capaian Skor Kompetensi Mengembangkan Komponen RPP, RPP, dan Poin Peningkatannya

\begin{tabular}{|c|c|c|c|c|}
\hline \multirow[t]{2}{*}{ No } & \multirow[t]{2}{*}{ Nama Komponen RPP } & \multicolumn{3}{|c|}{ Skor Rerata Mengembangkan Komponen RPP, RPP, dan Poin Peningkatan } \\
\hline & & Siklus1/Predikat & Siklus 2/Predikat & Poin Peningkatan \\
\hline 1 & Analisis KD & $59 / \mathrm{C}$ & $80 / \mathrm{B}$ & 11 \\
\hline 2 & Merumuskan Indikator & $76 / \mathrm{B}$ & $80 / \mathrm{B}$ & 4 \\
\hline 3 & $\begin{array}{l}\text { Merumuskan Tujuan Pembelajaran } \\
\text { Penilaian }\end{array}$ & $71 / \mathrm{C}$ & 77B & 6 \\
\hline 4 & Pendahuluan & $66 / \mathrm{C}$ & $81 / \mathrm{B}$ & 15 \\
\hline 5 & Kegiatan Inti & $76 / \mathrm{B}$ & 83/B & 7 \\
\hline 6 & Penutup & 78/B & $86 / \mathrm{B}$ & 8 \\
\hline 7 & Pengembangan Materi Pembelajaran & $67 / \mathrm{C}$ & 76/B & 9 \\
\hline 8 & Pemilihan Sumber & $56 / \mathrm{C}$ & 80/B & 24 \\
\hline 9 & $\begin{array}{l}\text { Pemilihan Media } \\
\text { RPP }\end{array}$ & $\begin{array}{l}\text { 54/Perlu bimbingan/K } \\
\text { 80/B }\end{array}$ & 78/B & 24 \\
\hline $\begin{array}{l}10 \\
11\end{array}$ & & $68 / \mathrm{C}$ & $\begin{array}{l}83 / \mathrm{B} \\
80 / \mathrm{B}\end{array}$ & $\begin{array}{r}3 \\
12\end{array}$ \\
\hline
\end{tabular}

\section{Keterangan:}

Predikat Nilai

Amat Baik (AB) $91 \leq$ Skor $\leq 100$

Baik (B) $76 \leq$ Skor $\leq 90$

Cukup (C) $56 \leq$ Skor $\leq 75$

Kurang (K) Skor $\leq 55$

Tabel 4. Rekapitulasi Persentase Capaian Predikat Nilai pada Siklus I dan II

\begin{tabular}{ccccc}
\hline \multicolumn{2}{c}{ Persentase (\%) Predikat Nilai Kompetensi Mengembangkan Komponen RPP } \\
\hline \multicolumn{2}{c}{ PTS Siklus I } & \multicolumn{2}{c}{ PTS Siklus II } \\
\hline K (perlu bimbingan) & Cukup (C) & Baik (B) & Cukup (C) & Baik (B) \\
\hline $\mathbf{1 0}$ & 50 & 40 & 0 & 100
\end{tabular}


Tabel 2. Rekapitulasi Skor Kompetensi Guru Mengembangkan Sepuluh Komponen RPP pada Siklus I dan II

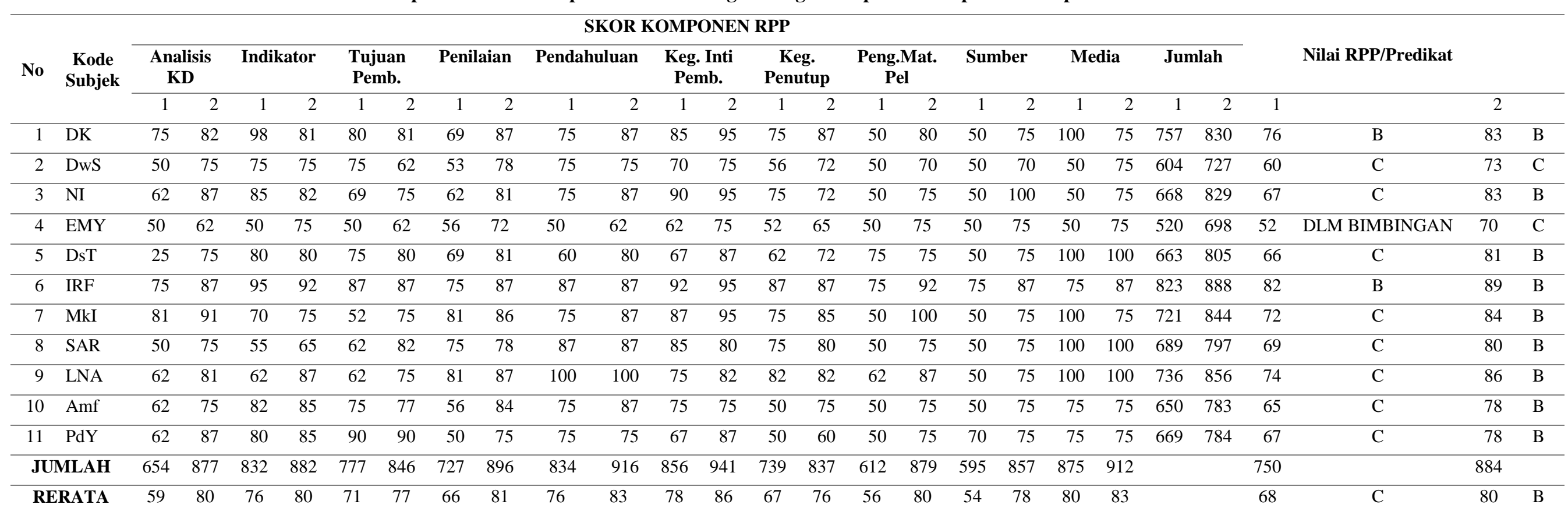

Keterangan: Capaian Nilai Kompetensi Mengembangkan RPP Setiap Subjek dan Nilai Rerata

1. Pada siklus I capaian nilai baik $(B)=2$ subjek $=18,18 \%$; nilai cukup $C=72,73 \%$; nilai kurang (K/dalam bimbingan) $=9,09 \%$

2. Pada siklus II capaian nilai baik $(B)=9$ subjek $=81,82 \%$, nilai cukup $C=18,18 \%$.

3. Nilai rerata kompetensi mengembankan RPP siklus I Cukup = C; Nilai rerata siklus II Baik (B) 
Hasil penelitian pada siklus I yang disajikan pada tabel 3 dan 4 memberi informasi bahwa skor rerata kompetensi guru mengembangkan komponen RPP bervariasi. Skor terendah sebesar 54 dengan nilai berpredikat kurang/masih perlu bimbingan, adalah kompetensi pemilihan sumber pembelajaran. Hal ini terjadi karena sumber yang digunakan hanya berupa buku teks (terbatas pada abuku tematik siswa dan buku tematik guru), tanpa menggunakan sumber lain yang relevan, misal artikel, majalah, koran, dan internet. Dengan keterbatasan penggunaan sumber pelajaran inilah yang mengakibatkan subjek belum bisa baik kompetensi memilih sumber yang relevan dengan tujuan pembelajaran. Sementara itu, jika ditinjau pesan yang tersurat dalam komponen RPP K-13 poin " $k$ " menyebutkan sumber belajar yang digunakan dapat berupa buku, media cetak dan elektronik, alam sekitar, dan sumber belajar lain yang relevan (Permendikbud Nomor 22 Tahun 2016). Dari pesan ini dapat dipahami bahwa sumber belajar yang digunakan perlu bervariasi, dan harus relevan dengan tujuan pembelajaran yang berarti relevan pula dengan KD.

Skor rerata komponen RPP mengembangkan materi pembelajaran yang dicapai sebesar 56 dengan nilai berpredikat "cukup". Capaian skor tersebut disebabkan hasil pengembangan materi pembelajaran rata-rata belum memuat perencanaan materi tambahan kekinian/yang mutakhir, atau belum relevan dengan tujuan pembelajaran, atau hanya menyalin materi dari buku teks. Jadi materi pembelajaran yang direncanakan dalam RPP belum seperti yang diharapkan oleh kurukulum 2013. Kompetensi mengembangkan materi pembelajaran terkait dengan kompetensi meganalisis KD seperti yang telah diuraikan teerdahulu. Jika hasil analisis KD menghasilkan fakta dan konsep yang tidak mencerminkan pesan KD, maka pengembangan materi pembelajran menjadi tidak/belum relevan dengan KD. Pernyataan ini didukung oleh deskripsi komponen RPP poin " $h$ " yang dimuat dalam Standar Proses Tahun2016 yang berbunyi fakta, konsep, prinsip, dan prosedur yang relevan (maksudnya relevan dengan KD) harus termuat dalam materi pembelajaran, sesuai dengan rumusan indikatornya (Permendikbud Nomor 22 Tahun 2016). Kondisi seperti ini disebabkan oleh keterbatasan sumber yang digunakan. Dengan keterbatasan sumber pembelajaran, maka wawasan keilmuan kurang memadai sehingga sulit menemukan materi kekinian/mutakhir apa yang layak disajikan untuk menambah wawasan keilmuan.

Skor rerata tertinggi dicapai oleh kompetensi memilih media pembelajaran, dengan capaian skor rerata sebesar 80 dengan nilai predikat "baik". Capaian ini terjadi karena media yang dipilih relevan dengan materi pembelajaran dan mendukung pencapaian tujuan pembelajaran, selain itu media yang akan digunakan dalam dalam pembelajaran sudah lebih dari satu/bervariasi. Temuan PTS ini ini senada dengan hakikat media pembelajaran yang dimuat dalam Standar Proses Tahun 2016 yang berbunyi media pembelajaran merupakan alat untuk membantu proses pembelajaran yang relevan dengan materi pembelajaran. Jadi dari temuan ini dapat dimaknai dengan media (sebagai alat untuk membantu proses pembeljaran), maka dengan media yang relevan dapat mengakibatkan proses pembelajaran menjadi lebih kondusif, khususnya bagi siswa. Siswa merasa tidak monoton dalam proses belajarnya. Temuan penelitian lain yang mendukung hasil PTS ini adalah temuan dari Chang Kim (2014) dalam Ratnawati (2018) yang mengatakan penggunaan media pembelajaran yang relevan dengam materi ajar dapat meningkatkan kualitas pembelajaran. Jadi artinya memilih media yang relevan dengan materi pembelajaran menjadi penting dalam merancang pembelajaran (Barkah et al., 2019)

Skor rerata kompetensi merumuskan indikator sebesar 76 dengan predikat "baik" lebih tinggi 5 poin daripada skor rerata kompetensi merumuskan tujuan pembelajaran sebesar 71 dengan predikat "cukup". Hal seperti ini disebabkan oleh kekurang tepatan/kurang sinkron pemilihan unsur $\mathrm{C}$ (condition/kondisi) dengan behaviour dan kekurang lengkapan unsur tujuan pembelajaran sebagai faktor penentu penilaian kualitas rumusan tujuan pembelajaran seperti yang dituliskan dalam "Instrumen Lembar Telaah RPP K-13 dalam Kegiatan Pendampingan Implentasi K-13 Bagi Kepala Sekolah dan Guru”. Dalam lembar telaah RPP secara tegas menyatakan tujuan pembelajaran yang ideal memuat empat unsur, yaitu unsur A (Audience/siswa) - B (Behaviour/perubahan perilaku/hasil belajar) - C (Condition/keadaan yang dilakukan siswa dalam kegiatan belajar untuk mencapai tujuan pembelajaran) - D (Degree/batasan tingkat ketercapaian hasil belajar). Sehingga jika dalam rumusan tujuan pembelajaran tidak lengkap memuat 4 unsur tersebut serta kurang sinkron pemilihan kosa kata untuk unsur " $C$ " dengan unsur " $B$ " maka jelas akan mengurangi skor. Selain itu, pemilihan KKO pada indikator dan tujuan pembelajaran yang tidak tepat dengan pesan KD menyebabkan tidak berhasilnya pembelajaran karena KD tidak tercapai. Pernyataan ini senada dengan pernyataan pada komponen RPP poin " $\mathrm{f}$ " yang berbunyi: Penggunaan KKO dalam rumusan tujuan pembelajaran yang dirumuskan berdasarkan KD bertujuan agar kompetensi pengetahuan, sikap, dan keterampilan dapat diukur dan diamati (Permendikbud Nomor 22 Tahun 2016).

Ketidaksinkronan antara kompetensi merumuskan indikator dengan tujuan pembelajaran ditinjau dari ketepatan pemilihan KKO berdampak terhadap kompetensi merancang alat penilaian dari aspek kognitif dan keterampilan (Satrio, 2016). Hal ini dapat dipahami karena pemilihan KKO yang tidak tepat mengakibatkan tujuan pembelajaran yang dirumuskan berdasarkan KD menjadi tidak teramati dan tidak terukur sehingga skor rerata kompetensi merancang alat penilaian yang dicapai lebih rendah dengan skor rerata sebesar 66 dengan nilai berpredikat “cukup". Hal ini kontradiksi dengan pernyataan pada komponen RPP poin "f" yang berbunyi: Penggunaan KKO dalam rumusan tujuan pembelajaran yang dirumuskan berdasarkan KD bertujuan agar kompetensi pengetahuan, sikap, dan keterampilan dapat diukur dan diamati (Permendikbud Nomor 22 Tahun 2016).

Nilai untuk kompetensi mengembangkan komponen pendahuluan dan kegiatan inti mencapai nilai dengan predikat baik dengan skor 76 dan 78. Capaian seperti ini dapat dipahami, karena pada komponen pendahuluan dan kegiatan inti yang ideal memuat sembilan macam aktivitas belajar, sementara itu yang dibuat oleh subjek hanya antara 6-7 aktivitas saja, maka dari itu hasilnya belum optimal. Jika sembilan macam aktivitas belajar pada pendahuluan dan kegiatan inti terpenuhi maka akan dicapai 
skor maksimal 100 dengan predikat nilai “amat baik". Sembilan aktivitas belajar dalam pendahuluan, meliputi penyiapan aktivitas fisik dan psikis siswa dengan sapaan dan pemberian salam sampai dengan yang kesembilan aktivitas penguatan karakter. Sementara itu, sembilan aktivitas kegiatan inti pembelajaran mencakup memuat rancangan pembelajaran sesuai dengan kompetensi yang akan dicapai/sesuai tujuan pembelajaran sampai dengan berbagai aktivitas pengelolaan kelas secara individu, kelompok, dan klasikal (Instrumen Telaah RPP K-13 Pendampingan Implementasi K-13 Bagi Kepala Sekolah dan Guru Tahun 2017).

Pada kegiatan pendahuluan 2-3 komponen kegiatan sering ditinggalkan oleh subjek sehingga capaian skor belum dapat optimal. Aktivitas pendahuluan yang pada umumnya ditinggalkan adalah aktivitas (a) penyampaian manfaat pembelajaran, (b) penyampaian rancangan aspek yang akan dinilai dalam pembelajaran pada waktu pembelajaran berlangsung, dan (c) penyampaian rencana langkah kegiatan yang akan dilakukan selama pembelajaran berlangsung, dan (d) pengajuan pertanyaan yang menantang siswa untuk motivasi. Sementara itu, komponen kegiatan inti yang sering ditinggalkan/tidak dibuat adalah (a) aktivitas memfasilitasi siswa mengajukan pertanyaan apa, mengapa, dan bagimana yang berguna untuk menumbuhkan partisipasi aktif siswa, (b) rancangan kegiatan siswa mengamati, dan (c) mencantumkan aktivitas siswa mengasosiasikan data dan informasi yang dikumpulkan.

Nilai rerata kompetensi mengembangkan komponen penutup pembelajaran/kegiatan akhir pembelajaran mencapai nilai dengan predikat cukup dengan skor rerata 67. Terjadinya kondisi seperti ini dikarenakan dalam kegiatan menutup pembelajaran belum memenuhi syarat rumusan menutup pembelajaran yang ideal (belum memuat aktivitas tindak lanjut dalam bentuk pemberian tugas pengayaan). Idealnya dalam kegiatan menutup pembelajaran memuat tiga aktivitas, yaitu siswa menyimpulkan/merangkum materi pembelajaran, merefleksi proses dan materi pembelajaran, dan tidak lanjut dengan memberikan arahan kegiatan belajar berikutnya dan tugas pengayaan (Instrumen Telaah RPP K-13 Pendampingan Implementasi K-13 Bagi Kepala Sekolah dan Guru 2017).

Hasil penelitian yang terpenting pada siklus I capaian skor rerata kompetensi mengembangkan RPP masih sebesar 68 dengan nilai berpredikat cukup). Pada siklus I ditemukan enam (6) komponen RPP yang nilai reratanya masih berpredikat cukup, dengan skor antara 56-71. Selain itu, ada satu komponen dengan nilai berpredikat kurang/perlu bimbingan dengan skor 54 yaitu komponen memilih sumber pembelajaran. Jadi, kesimpulan hasil PTS siklus I belum mencapai target PTS untuk mencapai nilai dengan predikat baik. Temuan penting PTS siklus1 adalah (a) pemilihan sumber perlu bervariasi untuk memperluas wawasan pengetahuan dari media cetak maupun elektronik yang dapat mendukung pencapaian kompetensi yang tersurat maupun yang tersirat dalam KD; (b) diperlukan ketajaman dalam mengidentifikasi fakta dan konsep yang tersurat dalam KD, untuk mempermudah dalam mengembangkan indikator, tujuan pembelajaran dan alat penilaian domain kognitif dan psikomotor/skill; (c) diperlukan pemantapan pemahaman kondisi (C) dan perubahan perilaku belajar (B) dalam merumuskan tujuan pembelajaran agar indikator dapat tercapai melalui proses belajar yang sesuai.

Berdasarkan hasil refleksi ini maka direkomendasikan PTS dilanjutkan ke siklus II dengan prioritas perbaikannya berdasarkan perolehan nilai reratanya. Secara berurutan, komponen-komponen RPP yang dimaksudkan adalah (a) pemilihan sumber pembelajaran, (b) merancang kegiatan menutup pelajaran, (c) merancang penilaian pengetahuan/KI 3, (d) merumuskan indikator, (e) menganalisis KD (Koszalka et al., 1999; Taorina et al., 2018; Sari dkk, 2018). Kompetensi menganalisis KD dan merumuskan indikator inilah yang menjadi fokus garapan di siklus II karena diharapkan dengan peningkatan pada kompetensi menganalisis KD dan merumuskan indikator yang mencerminkan pencapaian KD, maka kompetensi mengembangkan komponen RPP yang lainnya akan ikut meningkat pula.

\section{Penelitian Tindakan Sekolah Siklus II}

Pelaksanaan lesson study pada siklus II tidaklah selengkap dan selancar pada siklus I karena kondisi sekolah di setiap semester genap tahun pelajaran penuh dengan kegiatan yang sangat menyita waktu guru untuk mengurusi kegiatan tersebut. Sebagai contoh adalah kegiatan di awal semester genap di bulan Januari - Febuari sekolah mulai dengan persiapan penerimaan peserta didik baru sehingga kegiatan lesson study tahap plan dalam kegiatan diskusi kelompok kecil berjalan di luar jam kerja sehingga tidak ada pemantauan langsung dari peneliti. Diskusi kelompok kecil dilakukan oleh masing-masing kelompok kecil tergantung kesepakatan kelompok masing-masing; jadi tidak seperti pada siklus 1 yang memang tersedia waktu dan tempat khusus untuk diskusi dan terpantau dengan baik. Namun berkat kesadaran dan tanggungjawab masing-masing subjek dapat menyelesaikan tugas dengan baik, walau tidak tepat waktu.

Hasil kegiatan diskusi tahap plan adalah kegiatan pemilihan KD baru untuk dikembangkan menjadi sebuah RPP. Karena keterbatasan tenaga guru maka pelaksanaan tahap do di luar jam pembelajaran. Jika tidak ditempuh dengan cara seperti itu maka kemungkinan dapat terselesaikan kecil. Dari tahap do tersebut dihasilkan kasil kerja subjek berupa data sepuluh kompetensi mengembangkan komponen RPP. Kesibukan tugas sekolah yang menghambat pelaksanaan tahap see/refleksi adalah kegiatan ujian praktik bagi siswa kelas VI, ujian Center Progression Test (CPT) Cambridge untuk kelas I dan II dan International Progression Test (IPT) Cambridge untuk kelas 3-5, dan Ujian Sekolah dan Ujian Sekolah Berstandar Nasional bagi kelas VI.

Terkait dengan kegiatan tersebut maka tahap see/refleksi diganti deengan pendampingan dan observasi langsung terhadap dokumen hasil penyelesaian tugas kegiatan tabel kerja $1-5$ dan RPP oleh peneliti. Jadi, tahap see berlangsung tanpa melalui diskusi pleno seperti pada siklus 1 . Hasil kegiatan oleh subjek PTS pada akhir kegiatan siklus II memberikan hasil yang menggembirakan karena semua komponen RPP yang disusun menunjukkan peningkatan kualitatif meningkat menjadi nilai 
dengan predikat baik. Layanan pendampingan dari peneliti sebagai pengganti tugas mengkoordinasi kegiatan plan dan do dapat terwakili, dan hasilnyapun tidak mengecewakan, walau secara rata-rata belum dapat mencapai nilai akhir dengan predikat amat baik. Namun, rata-rata capaian nilai akhir PTS dengan predikat baik sudah tercapai, jadi sudah sesuai dengan target capaian PTS yang ditetapkan.

Dipilihnya kegiatan pendampingan oleh peneliti pada pelaksanaan tahapan-tahapan lesson study sebagai pengganti pemantauan langsung karena terinspirasi oleh temuan penelitian oleh Nurkhan (2016) yang menunjukkan bahwa "teknik pendampingan dalam kegiatan dalam rangka untuk meningkatkan kemampuan guru SD sasaran Kurikulum 2013 dalam pengelolaan penilaian dengan peningkatan rata-rata 28,7 poin atau 23,91\%”. Atas dasar temuan inilah peneliti meyakini bahwa dengan model pendampingan dapat diterapkan untuk mengatasi kendala keberlanjutan PTS siklus II walau para subjek disibukkan oleh tugas rutin kedinasan yang padat. Terbukti model pendampingan tersebut memberikan hasil seperti yang diharapkan.

Pendampingan yang dilakukan dalam PTS siklus II ini berupa layanan konsultasi interaktif terhadap kesulitan yang dihadapi subjek pada tahap do dan see. Pada proses pendampingan ini peneliti sebagai pendamping mempunyai peran sebagai konsultan bagi subjek penelitian. Selain sebagai konsultan, pendamping berperan juga sebagai motivator, inovator, dan negosiator. Jika tidak dimotivasi melalui negosiasi yang fleksibel, maka dengan kesibukan rutin kedinasan yang tinggi, PTS siklus 2 terancam tidak berlanjut. Aktivitas pendampingan seperti yang dilakukan di atas senada dengan pengertian pendampingan menurut Kamil (2010) dalam Nurkhan (2016) mengartikan "pendampingan sebagai kegiatan interaktif, konsultatif, inovatif, motivatif, dan negosiatif antara pendamping dengan yang didampingi". Jadi, pendampingan menjadi solusi yang tepat untuk mengatasi masalah kemacetan keberlanjutan PTS ini.

Informasi yang dapat diperoleh dari data pada tabel 2 menunjukkan pada siklus II sudah tidak ditemukan subjek dengan capaian nilai berpredikat "perlu bimbingan". Hal tersebut ditunjukkan oleh hanya adanya dua varian nilai yaitu nilai C dan B saja. Subjek yang mencapai nilai C hanya dua orang (18,18\%), sedangkan yang sembilan orang subjek sisanya (81,82\%) sudah mencapai nilai B. Hasil penelitian pada siklus II yang disajikan pada tabel 3 di atas memberi informasi bahwa skor rerata kompetensi guru mengembangkan komponen RPP bervariasi. Semua komponen RPP secara rata-rata sudah berada pada posisi nilai dengan predikat baik. Skor terendah sebesar 76 dengan nilai berpredikat baik adalah merancang kegiatan penutup pembelajaran dengan peningkatan kuantitatif sebesar sembilan poin, dan mengalami peningkatan secara kualitatif dari predikat "cukup" pada siklus 1meningkat menjadi "baik" pada siklus II. Hal ini terjadi karena rata-rata subjek penelitian sudah merancang kegiatan tindak lanjut dalam komponen penutup, walau masih ada bentuk tindak lanjut yang diberikan kepada siswa belum sesuai dengan KD. Selain itu, rencana pembelajaran yang akan datang pada umumnya juga belum ditulis dalam penutup pembelajaran. Hasil ini belum semuanya sesuai dengan ketentuan dalam Standar Proses Tahun 2016, yang menyatakan kegiatan menutup pelajaran merupakan kegiatan guru dan siswa dalam merefleksi pembelajaran, merangkum hasil pembelajaran, dan merancang kegiatan tindak lanjut dalam bentuk pengayaan, dan menyampaikan rencana pembelajaran yang akan datang (Permendikbud No.22 Tahun 2016).

Urutan berikutnya adalah merancang tujuan pembelajaran dan indikator. Skor rerata merumuskan indikator selalu lebih tinggi dibandingkan merumuskan tujuan pembelajaran baik di siklus I maupun II. Hal ini terjadi karena kegiatan merumuskan tujuan pembelajaran memerlukan pemikiran yang lebih kompleks dibandingkan dengan kegiatan merumuskan indikator. Dalam kegiatan merumuskan indikator cukup memilih kata kerja opersional yang sesuai dengan aspek kognitif dan keterampilan yang mencerminkan pencapaian KD. Jika merumuskan tujuan pembelajaran perlu kejelian dalam memilih kosa kata yang tepat untuk kondisi belajar (C) dan tingkat pencapaian/degree (D) agar proses pembelajaran untuk mencapai tujuan pembelajaran seperti yang tersurat dalam KD dapat tercapai sesuai batasan/tingkat capaian yang sudah ditentukan. Pemilihan kondisi belajar yang tidak sinkron dengan behaviour (hasil belajar/perilaku belajar) akan mengakibatkan proses pembelajaran untuk mencapai tujuan pembelajaran menjadi kacau atau tidak terarah, sehingga kompetensi yang dipesankan oleh KD menjadi tidak tercapai.

Dua macam komponen RPP (merumuskan indicator dan tujuan pembelajaran) pada siklus II sama-sama mengalami peningkatan. Secara kuantitatif kompetensi merumuskan tujuan pembelajaran meningkat enam poin dan mampu meningkatkan predikat nilai dari "cukup" meningkat menjadi "baik". Peningkatan ini dapat terjadi karena rata-rata subjek penelitian sudah menggunakan kosa kata untuk kondisi (C) sudah sesuai dengan hakikat proses pembelajaran yang akan dilakukan siswa untuk mencapai pesan dalam KD. Sementara itu untuk kompetensi merumuskan indikator stagnan pada predikat "baik". Jadi pada siklus II ini dua macam komponen RPP ini sudah berada pada posisi predikat "baik". Berikut ini dicontohkan sinkronisasi antara KD indikator - tujuan pembelajaran dengan unsur kondisi (C) yang sesuai - kegiatan/proses pembelajaran untuk mencapai KD, oleh salah seorang guru subjek, untuk muatan pelajaran Bahasa Indonesia Kelas/Semester: III/1 untuk KD Pengetahuan (3.5) dan Keterampilan (4.5). 
Tabel 5. Contoh Sinkronisasi KD-Indikator-Tujuan Pembelajaran-Proses Pembelajaran

\begin{tabular}{|c|c|c|c|}
\hline KD & Indikator & Tujuan Pembelajaran & Kegiatan/Proses Pembelajaran \\
\hline $\begin{array}{l}\text { KD } 3.5 \text { Menggali informasi } \\
\text { tentang cara-cara perawatan } \\
\text { tumbuhan dan hewan melalui } \\
\text { bacaan. }\end{array}$ & $\begin{array}{l}\text { Menemukan informasi } \\
\text { mengenai cara merawat } \\
\text { hewan melalui teks } \\
\text { bacaan }\end{array}$ & $\begin{array}{l}\text { Melalui mengamati gambar dan } \\
\text { membaca teks bacaan, siswa dapat } \\
\text { menemukan langkah-langkah cara } \\
\text { merawat hewan, sesuai informasi } \\
\text { dalam teks yang dibaca. }\end{array}$ & $\begin{array}{l}\text { - Siswa mengamati gambar cara } \\
\text { merawat hewan dan membaca } \\
\text { teks bacaan cara merawat } \\
\text { hewan, untuk menemukan } \\
\text { langkah-langkah cara merawat } \\
\text { hewan. }\end{array}$ \\
\hline
\end{tabular}

KD 4.5 Menyajikan informasi tentang cara-cara perawatan tumbuhan dan hewan dalam bentuk tulis dan visual menggunakan kosa kata baku dan kalimat efektif.

\author{
Membuat laporan \\ sederhana hasil \\ pengamatan cara-cara \\ merawat hewan dengan \\ kosa kata baku dan \\ kalimat efektif
}

Melalui diskusi kelompok, siswa menulis laporan hasil pengamatan secara sederhana tentang langkahlangkah merawat hewan dengan menggunakan kosa kata baku dan kalimat efektif, dengan benar dan runtut
- Siswa berdiskusi kelompok untuk membuat laporan tertulis secara sederhana langkahlangkah merawat hewan dengan menggunakan kosa kata baku dan kalimat efektif.

Keterangan: Pada rumusan tujuan pembelajaran di atas unsur kondisi (C) adalah melalui mengamati gambar dan membaca buku teks, unsur $\mathrm{C}$ tersebut sudah padu dengan KD dan rumusan indikatornya. Akibatnya rumusan proses pembelajarannya mendukung proses pencapaian pesan kompetensi dalam KD.

Pada siklus II, capaian nilai kompetensi merumuskan indikator pada predikat "baik". Capaian ini diikuti oleh capaian kompetensi merumuskan tujuan pembelajaran dan merancang penilaian juga sama-sama "baik". Peningkatan kompetensi yang mencolok, baik secara kuantitatif maupun secara kualitatif adalah kompetensi memilih sumber pembelajaran. Secara kuantitatif kompetensi memilih sumber pembelajaran meningkat cukup tinggi yaitu sebesar 24 poin sehingga mampu mendongkrak peningkatan kualitatifnya dari nilai dengan predikat "perlu bimbingan" meningkat menjadi nilai dengan predikat "baik". Peningkatan ini terjadi karena secara rata-rata subjek sudah menggunakan sumber yang lebih bervariasi, tidak hanya menggunakan buku teks saja. Langkah yang ditempuh untuk meningkatkan nilai kompetensi memilih sumber belajar sudah sesuai dengan ketentuan komponen RPP poin "k" dalam Standar Proses Tahun 2016 yang menyatakan sumber belajar dapat berupa buku, media cetak dan eletronik, alam sekitar, atau sumber belajar lain yang relevan (Permendikbud Nomor 22 Tahun 2016).

Semakin bervariasinya sumber pembelajaran yang digunakan maka subjek semakin kaya wawasan pengetahuan, khususnya yang terkait dengan topik yang dibelajarkan kepada siswa. Maka dari itu dapat dipahami pula bahwa peningkatan kompetensi memilih sumber pembelajaran diikuti oleh meningkatnya kompetensi mengembangkan materi pembelajaran. Kompetensi mengembangkan materi pembelajaran meningkat 24 poin di siklus II sehingga dapat meningkatkan predikat nilai dari "cukup" menjadi "baik". Dengan semakin bervariasinya sumber belajar yang dipakai, mengakibatkan semakin banyak pengetahuan yang terkait dengan fakta, konsep, prinsip, dan prosedur yang dikuasai, sehingga membantu mempermudah untuk menemukan unsur-unsur yang diperlukan untuk mengembangkan materi pembelajaran. Hal ini senada dengan ketentuan materi pembelajaran yang dimuat dalam komponen RPP K-13, poin " $h$ " yang berbunyi materi pembelajaran memuat fakta, konsep, prinsip, dan prosedur yang relevan (relevan dengan KD) sesuai dengan rumusana indicator capian kompetensi (maksudnya KD).

Urutan berikutnya adalah kompetensi merancang skenario pembelajaran. Hasil penelitian pada siklus 2 berada pada nilai dengan predikat baik. Peningkatan secara kualitatif dan kuantitatif hanya terjadi pada sub komponen merancang kegiatan menutup pelajaran. Peningkatan kuantitatif sebesar sembilan poin, dari skor 67 di siklus I dengan predikat cukup, meningkat menjadi 76 di siklus II dengan nilai berpredikat baik. Sementara itu untuk dua sub komponen merancang kegiatan pendahuluan dan kegiatan inti pembelajaran tidak mengalami peningkatan predikat, tetapi mengalami peningkatan kuantitatif, masing-masing meningkat sebesar 7 poin dan 8 poin. Peningkatan kompetensi merancang skenario pembelajaran terjadi karena kegiatan merancang skenario pembelajaran adalah salah satu bentuk kecakapan keterampilan (Rahmi et al., 2017). Ketika di siklus II ini subjek sudah mulai terlatih bagaimana mengemas hasil kerja pada setiap tahap kegiatan untuk dijadikan sebuah RPP yang membentuk satu kesatuan yang utuh dan padu antar komponen skenario pembelajaran, berdasarkan pengalaman di siklus I.

Capaian skor kompetensi untuk komponen memilih media pada siklus II secara rata-rata juga hanya meningkat secara kuantitatif sebesar 3 poin, dari skor 80 di siklus I menjadi 83 di siklus II dengan nilai berpredikat sama-sama baik, jadi secara kualitatif tidak mengalami peningkatan. Temuan penting pada PTS siklus II adalah (a) dari 10 komponen RPP yang dirancang subjek, secara rata-rata semua sudah mencapai nilai dengan predikat baik dengan poin peningkatan yang bervariasi; (2) model pendampingan dapat dijadikan solusi untuk mengatasi keterbatasan waktu para peneliti untuk melaksanakan lesson study secara penuh, dan memberikan hasil dengan rata-rata baik, dan (c) kompetensi mengembangkan RPP pada siklus II mengalami peningkatan baik secara kuantitatif maupun secara kualitatif; peningkatan secara kuantitatif dari siklus II ke II sebesar 12 poin, sedangkan secara kualitatif meningkat satu tingkat lebih tinggi dari nilai cukup meningkat menjadi baik. Berdasarkan hasil ini, maka PTS 2 dihentikan karena sudah mencapai nilai rerata baik sesuai dengan target yang ditetapkan. 


\section{SIMPULAN}

Lesson Study sebagai model pembinaan profesi pendidik melalui pengkajian pembelajaran secara kolaboratif dan berkelanjutan berlandaskan prinsip-prinsip kolegalitas dan mutual learning untuk membangun komunitas belajar, mampu meningkatkan kompetensi guru SD Laboratorium UM Blitar dalam mengembangkan RPP sebesar 24 poin; dari capaian skor rerata di siklus 1 sebesar 68 dengan "nilai cukup", meningkat menjadi skor 80 dengan "nilai baik". Setiap RPP terdiri dari sepuluh subkomponen. Masing-masing komponen dari komponen ke satu sampai ke sepuluh dikembangkan secara berurutan dimulai menganalisis KD sampai dengan memilih media pembelajaran sehingga menghasilkan satu RPP yang utuh, siap digunakan dalam pelaksanaan pembelajaran di kelas. Hasil analisis KD yang tepat menentukan tingkat kesesuaian rumusan indikator yang mencerminkan capaian KD. Rumusan indikator yang tepat menentukan rumusan tujuan pembelajaran. Rumusan tujuan pembelajaran yang tepat berdampak pada ketepatan langkah pembelajaran dalam kegiatan inti untuk mengantarkan siswa melakukan aktivitas pembelajaran yang ideal untuk mencapai tujuan pembelajaran. Tujuan pembelajaran menjadi acuan merancang alat penilaian dari aspek kognitif dan keterampilan sebagai alat ukur pencapaian tujuan pembelajaran, dan secara tidak langsung sebagai alat ukur ketercapaian KD. Pelaksanaan lesson study pada siklus I berlangsung lancar, kondusif, dan partisipatif sesuai langkah-langkahnya. Pelaksanaan di siklus II pelaksanaan lesson study kurang maksimal, untuk megantisipasinya dilakukan pendampingan interaktif dan konsultatif langsung oleh peneliti. Kondisi seperti ini tidak menjadikan kendala terhadap tingkat keberhasilan PTS, terbukti hasil PTS siklus II menunjukkan adanya peningkatan capaian hasil penelitian sebesar 12 poin. Model pendampingan dapat dijadikan solusi untuk mengatasi keterbatasan waktu untuk melaksanakan Lesson Study secara penuh sesuai prosedur.

Berdasarkan simpulan hasil PTS disarankan sebagai berikut: (1) Saran kepada peneliti lain untuk dapatnya melakukan PTS sejenis dengan siklus yang lebih panjang, agar hasil penelitian lebih mantap, dan konsistensi hasil penelitian dapat tercapai, (2) Saran kepada subjek penelitian agar menerapkan tahap-tahap pengembangan RPP dengan runtut, agar RPP sebagai instrumen guru dalam pembelajaran menjadi lebih berkualitas dan lebih applicable.

\section{DAFTAR RUJUKAN}

Arsy, D. K. W. S. (2014). Kajian Implementasi Lesson Study pada Pengembangan Pembelajaran IPA Berbasis Inkuiri dan PBL Kelas VII SMP untuk Meningkatkan Hasil Belajar Peserta Didik dan Keprofesionalan Guru. Skripsi tidak diterbitkan. Universitas Negeri Malang, Malang.

Astuti, S. R. I. (2018). Analisis Kesesuaian Komponen RPP dengan Tujuan Pembelajaran Mata Pelajaran Bahasa Indonesia di SMA Negeri 20 Medan Tahun Pembelajaran 2017/2018. Disertasi tidak diterbitkan. Universitas Negeri Medan, Medan.

Bachri, B. S. (2010). Implementasi Pengembangan Content Curriculum dalam Proses Perencanaan Pembelajaran. Jurnal Teknologi Pendidikan, 1, 0.

Bagus, Y.A.D.E., \& Sujatmiko, B. (2019). Pengembangan Aplikasi Validasi Soal Berdasarkan Kesesuaian dengan Kata Kerja Operasional dan Analisa Butir Soal Berbasis. IT-EDU, 4(01), 39-46.

Barkah, T., Warneri, W., \& Buwono, S. Analisis Penggunaan Media Dalam Pembelajaran Sosiologi di Kelas XI IPS MAS AlJihad Pontianak. Jurnal Pendidikan dan Pembelajaran Khatulistiwa, 8(10), 3-10.

Dinas Pendidikan dan Kebudayaan Kota Blitar. (2017). Instrumen Telaah RPP K-13. Makalah disajikan dalam Kegiatan Pendampingan Implementasi K-13 Bagi Kepala Sekolah dan Guru SD se Kota Blitar. Kegiatan diselenggarakan pada bulan Juni 2017 di SDN Karangtengah 3 Kota Blitar.

Fernandez, C. (2002). Learning from Japanese Approaches to Professional Development: The Case of Lesson Study. Journal of Teacher Education, 53(5), 393-405.

Hendayana, S. (2006). Lesson Study: Suatu Strategi untuk Meningkatkan Keprofesionalan Pendidik. Bandung: FPMIPA UPI dan JICA.

Kamil, M. (2010). Model Pendidikan dan Pelatihan (Konsep dan Aplikasi). Bandung: Alfabeta.

Kim, D., \& Bolger, M. (2016). Analysis of Korean Elementary Pre-Service Teachers' Changing Attitudes about Integrated STEAM Pedagogy Through Developing Lesson Plans. International Journal of Science and Mathematics Education, 15(4), 587-605. doi:10.1007/s10763-015-9709-3

Koszalka, T. A., Breman, J., \& Moore, M. K. (1999). Sharing lesson plans over the World Wide Web: Important Components. Education and Information Technologies, 4(2), 143-151.

Lewis, C. C., Perry, R. R., \& Hurd, J. (2009). Improving Mathematics Instruction Through Lesson Study: A Theoretical Model and North American Case. Journal of Mathematics Teacher Education, 12(4), 285-304.

Lewis, C., Perry, R., \& Murata, A. (2006). How Should Research Contribute to Instructional Improvement? The Case of Lesson study. Educational researcher, 35(3), 3-14.

Lubis, K. A., Djulia, E., \& Hasruddin, H. (2017). Analisis Komponen RPP Guru Biologi di SMA Negeri Se-Kabupaten Mandailingnatal. Jurnal Pendidikan Biologi, 6(3), 367-370.

Munasik, M. (2015). Kemampuan Guru Sekolah Dasar dalam Menerapkan Pembelajaran Tematik di Sekolah. Jurnal Pendidikan, 15(2), 105-113.

Nurkhan, N. (2016). Peningkatan kemampuan pengelolaan penilaian kurikulum 2013 melalui pendampingan bagi guru sekolah dasar. Refleksi Edukatika: Jurnal Ilmiah Kependidikan, 7(1), 44-54. 
Nurkhan. (2016). Peningkatan Kemampuan Pengelolaan Penilaian Kurikulum 2013 melalui Pendampingan bagi Guru Sekolah Dasar. Jurnal Refleksi Edukatika, 7(1), 45-55.

Owiny, R. L., Hollingshead, A., Barrio, B., \& Stoneman, K. (2019). Engaging Preservice Teachers in Universal Design for Learning Lesson Planning. Inclusion, 7(1), 12-23. doi:10.1352/2326-6988-7.1.12

Pane, A., \& Dasopang, M. D. (2017). Belajar dan pembelajaran. Fitrah: Jurnal Kajian Ilmu-ilmu Keislaman, 3(2), 333 -352.

Peraturan Menteri Pendidikan dan Kebudayaan Nomor 22 tahun 2016. (2016). Peraturan Menteri Pendidikan dan Kebudayaan Nomor 21 Tahun 2016 tentang Standar Isi Pendidikan Dasar dan Menengah. Jakarta: Direktorat Jenderal Peraturan Perundang-Undangan Kementerian Hukum dan Hak Asasi Manusia Republik Indonesia.

Rahmatullah, M. (2016). The Relationship between Learning Effectiveness, Teacher Competence and Teachers Performance Madrasah Tsanawiyah at Serang, Banten, Indonesia. Higher Education Studies, 6(1), 169-181. http://dx.doi.org/10.5539/hes.v6n1p169.

Rahmi, R., Mini, R., \& Salim, A. (2017). Peran Perlibatan Diri Siswa sebagai Mediator dalam Hubungan antara Iklim Kelas dengan Sikap Kreatif Siswa SD Sekolah Alam. Jurnal Psikologi, 16(1), 79.

Rahmi, S., Mappiare-AT, A., \& Muslihati, M. (2017). Karakter Ideal Konselor dalam Budaya Bugis Kajian Hermeneutik terhadap Teks Pappaseng. Jurnal Pendidikan: Teori, Penelitian, dan Pengembangan, 2(2), 228 - 237.

Ratnawati, E. (2018). Pengelolaan media pembelajaran di Sekolah Dasar Negeri 1 Karangduren Kecamatan Sawit Kabupaten Boyolali (Unpublished Doctoral dissertation). Universitas Muhammadiyah Surakarta, Indonesia.

Retnosari, N., Susilo, H., \& Suwono, H. (2016). Pengaruh Model Pembelajaran Inkuiri Terbimbing Berbantuan Multimedia Interaktif terhadap Berpikir Kritis Siswa Kelas XI SMA Negeri di Bojonegoro. Jurnal Pendidikan: Teori, Penelitian, dan Pengembangan, 1(8), 1529-1535.

Sari, N. A., Akbar, S., \& Yuniastuti. (2018). Penerapan Pembelajaran Tematik Terpadu di Sekolah Dasar. Jurnal Pendidikan: Teori, Penelitian, dan Pengembangan, 3(12), 1572-1582.

Satrio, B. Y. D. (2016). Modul kimia berbasis EPUB untuk siswa tunanetra: Materi Larutan Elektrolit dan NonElektrolit. Inklusi, 3(1), 87-100.

Slamet, H., Subadi, T., Sutama, S., \& Khotimah, R. P. (2010). Peningkatan Kompetensi Guru melalui Lesson Study. WARTA, 13(1), 55-64.

Susilo, H., Chotimah, H., \& Sari, Y. D. (2009). Penelitian tindakan kelas sebagai sarana pengembangan keprofesionalan guru dan calon guru. Malang: Bayumedia Publishing.

Susilo, H., Husnul, C., Ridwan, J., \& Jumiati, Y. (2009). Lesson Study Berbasis Sekolah: Guru Konservatif Menuju Guru Inovatif. Malang: Bayumedia.

Taorina, R., Chandra, T., \& Sisworo, S. (2018). Pengetahuan Calon Guru Matematika tentang Kurikulum 2013 dalam Penyusunan RPP. Jurnal Pendidikan: Teori, Penelitian, dan Pengembangan, 3(12), 1520-1529.

Voss T., Goeze A., Marx C., Hoehne V., Klotz V., Schrader J. (2017) Using Digital Media to Assess and Promote School and Adult Education Teacher Competence. In: Buder J., Hesse F. (eds) Informational Environments. Springer, Cham 